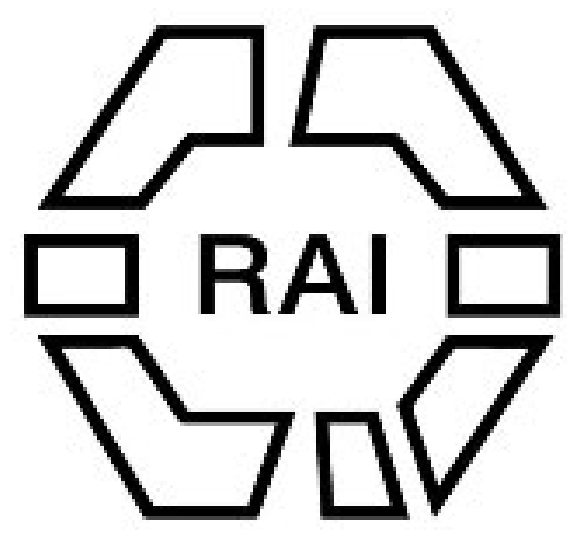

Religion and Family Among the Haidas (Queen Charlotte Islands)

Author(s): Charles Harrison

Source: The Journal of the Anthropological Institute of Great Britain and Ireland, Vol. 21 (1892), pp. 14-29

Published by: Royal Anthropological Institute of Great Britain and Ireland

Stable URL: http://www.jstor.org/stable/2842203

Accessed: 14/06/2014 11:51

Your use of the JSTOR archive indicates your acceptance of the Terms \& Conditions of Use, available at http://www.jstor.org/page/info/about/policies/terms.jsp

JSTOR is a not-for-profit service that helps scholars, researchers, and students discover, use, and build upon a wide range of content in a trusted digital archive. We use information technology and tools to increase productivity and facilitate new forms of scholarship. For more information about JSTOR, please contact support@ jstor.org.

Royal Anthropological Institute of Great Britain and Ireland is collaborating with JSTOR to digitize, preserve and extend access to The Journal of the Anthropological Institute of Great Britain and Ireland. 
From Dr. Beddoe.-La Necropoli di S. Lucia presso Tolmino del

Dr. Carlo Marchesetti. 8vo. Trieste. 1886.

From Dr. Carlo Marchesetri.-Atti del Museo Civico di Storia Naturale di Trieste. VIII.

From Cuthbert E. Peek, Esq.-Royal Geographical Society, Hints to Travellers. $8^{\circ}$.

From the AUtHoR.-Die Grenzen der niederdeutschen Sprache. Von Richard Andree. [From Globus. Bd. lix. Nr. 2 u. 3.] On certain mutilations practised by the natives of the Viti Islands. By Bolton S. Corney.

Notes on counting and measuring among the Eskimo of Point Barrow. By John Murdock.

The history of the Throwing Stick which drifted from Alaska to Greenland. By John Murdock.

A stuảy of Eskimo Bows in the U.S. National Museum. By John Murdock.

From the United States Geologrcal Survey.-Bulletin Nos. 58, 59,60,61, 63, 64, 66 ; Annual Report, IX ; Mineral Resources of the United States, 1888; Monographs, Vol. i.

From the Government of Perak.-The Perak Government Gazette. Vol. iv. No. 1.

From the Indian Office.-Epigraphia Indica and Record of the Archæological Survey of India. Part 6.

From the Editor.- -Journal of Mental Science. N.S. No. 120.

- L'Anthropologie. Tome ii. No. 1.

- Nature. Nos. 1111, 1112.

- Revue Scientifique. Tome xlvii. Nos. 7, 8.

- Science. Nos. 418, 419.

From the Society of ARTs.-Journal. Nos. 1995, 1896.

The Rev. C. HARRISON read a paper on Religion and Family among the Haidas.

\section{ReLigion and Family among the HaIDas (Queen Charlotte Islands).}

By Rev. Charles Harrison.

ThE Queen Charlotte Islands, the extreme north-western lands of British Columbia, lie in the Pacific Ocean between fifty-one and fifty-five degrees of north latitude. They comprise over 200 islands, their length being 220 miles and their greatest width sixty-three miles. Graham, Moresby, Prevost, and North Islands are the largest, extending eighty, seventy, fifteen, and eight miles respectively, and constitute eighty per cent. of their entire area. Dixon's Entrance on the north, with an average width of thirty miles, separates Graham Island from the Prince 
of Wales group in Alaska. Queen Charlotte Sound, from thirty to eighty miles across, lies between them and the mainland of the province. The nearest land is Stephen's Island, twentyeight miles east of Rose Spit, the extreme north-eastern part of Graham Island. Cape St. James, their most southerly point, is 140 miles north-west of Cape Scott, the northernmost land of Vancouver Island. The Queen Charlotte Islands were first discovered by Juan Perez, a Spanish navigator, on the 18th of July, 1774, and named Cabo de St. Margarita. In 1787 Captain Dixon was exploring the west coast of Vancouver on behalf of a London fur company, when he discovered other islands ahead of him. He came here through an entrance on the west coast, which has been known as Dixon's Entrance ever since. He then hoisted the British flag and named the islands after George the Third's queen, and they have been known by that name ever since. The first white men known to have landed upon the islands were a portion of the crew of the Iphigenia, under the command of Captain Douglass. They remained nine days in Parry Passage in 1788, trading with the natives. The most extensive explorations made of any portion of the islands were those of Captain Etienne Marchand in the French ship Solide. In 1791 he examined the shores bordering on Parry Passage and part of the west coast of Graham Island commencing from Frederick Island southward. Since that time, although several parties of prospectors have visited various parts of the islands, no systematic effort has been made to thoroughly explore the entire group. During the past eight years I have resided at Massett, Graham Island, and am the only white man thoroughly conversant with the Haida language. The ancient traditions of the Haidas concerning their religion and creation I have received verbally from some of the oldest chiefs. I have divided my subject into two parts:-1st, the Haida Deities ; 2nd, The Haida Creation.

\section{Part I.-The Haida Deities.}

The ancient Haidas believed in two important gods-one as Hierarch of the celestial sphere, and the other as sovereign of the lower regions. These two gods formerly lived together in happiness attended by other inferior gods, until a dispute arose as to light and darkness. Shānungetlagidas was the name of one and Hetgwaulana was the name of the other god. Shānungetlagidas always wished for light in their abode of happiness and was never sleepy or tired. On the contrary Hetgwaulana was never happy unless it was dark. He said that it was impossible to sleep if it were always light. So one 
day he was very angry and demanded that it should always be dark. Shānungetlagidas would not listen to this proposal and consequently a contest arose as to who should be the most powerful monarch in this land of gods. A battle accordingly took place, and the Chief of Light and his attendants prevailed and cast forth the Chief of Darkness and his followers into the lower regions. Thus it happens that where Shānungetlagidas is supreme it is always light, but, on the contrary, where Hetgwaulana is the chief it is always pitchy dark, and he is allowed to sleep undisturbed by the faintest ray of light. It is fully believed that Shānungetlagidas is the possessor of the sun and moon; he is also the creator of the stars and all the other luminaries that are supposed to exist in the kingdom of light. Hetgwaulana is credited with the origin of the clouds and darkness. As I have already stated, these two supreme deities had minor gods to assist them. All fevers are attributed to the god who resides in the sun. When he is offended by some action of theirs he visits the earth with the pestilence of smallpox and fevers. They try to propitiate him with offerings of berries cast into fire, and if they fail to regain his goodwill, they then take some portions of their daily food (chiefly smoked salmon or dry halibut) and throw it as far as they can into the salt water in order to gain the influence of the god of the sea, whom they believe to be more powerful than the god in the sun.

Whenever the Haidas camped near the beach, before they commenced to erect their tent and cook their food, they would invariably take some dry halibut and berries and cast into the fire to propitiate the god of the earth, and so secure his influence to protect them from danger during the night. The god of the earth did not require this food for himself, but carried it to the friends of those encamped who had died during the previous year. In case they should happen to be greedy, and throw but a scanty portion of their food into the fire, their deceased friends would become very angry, and within the next twelve months they all would most assuredly die.

The god of the clouds is another deity who inspires a feeling of awe and dread in the bosom of the bravest warrior. On a dull day, when the clouds are hanging low down, they firmly believe that this god is in search of a meal, and anyone caught out on such a day is bound to die before the expiration of six months, so as to furnish a dainty dish for this anthropophagous god. As the people are afraid of his cruel threat to catch all who come out on such a day, they almost always remain indoors. This god has a novel way of securing his prize. He comes down on the clouds and sits watching for any stray Indian. As soon as one comes near him he does not pounce upon his 
body. No! this would be too vulgar an action for a god to do. He merely seizes the spirit of the Indian, i.e., he draws the spirit out of the body and takes it with him on high; and in a very short space of time the body has to go in search of his spirit, and so becomes an easy victim of this cannibal god.

The Haidas did not fear the two great spirits as much as they feared the minor deities. They believed that Shānungetlagidas and Hetgwaulana were too great and independent to care very much for them while on earth, but were busy preparing habitations for them to live in after death. The two great guds were worshipped but not feared, and no one is able to give a definite answer as to what they believed they were or how they came into existence. They existed according to tradition, and that was sufficient for the Haidas. They also created all the inferior gods to assist them in their united kingdom above the clouds. If, however, they were in great trouble, they would evoke the aid of the Spirit of Light, and if they wished to bring an eternal curse on their enemies, they would pray and offer sacritices of fish to the Spirit of Darkness. Shanungetlagidas is supposed to have commanded the inferior gods to protect the Haida nation and to supply them with all the necessaries of life. Their supplications were addressed to this supreme chief through the god of the sun and the god of the sta. Their offerings were always made to the minor deities in order to secure their goodwill and assistance as mediators with the Great Chief whenever they were seriously ill and on the point of death. Ordinarily most of their religious rites and ceremonies have reference only to the sun god and the sea god.

Whenever a good Haida is about to die he sees a canoe manned by some of his bygone friends who come with the tide to bid him welcome to their domain. They are supposed to be sent by the god of death. 'The dying man sees them and is rejoiced to know that after a period passed within the city of death, he will, with his friends, be welcomed to the kingdom of Shānungetlagidas. His friends call him and bid him come. They say, "Come with us; come into the land of light; come into the land of great things; wonderful things; come into the land of plenty, where hunger is unknown; come with us and rest for evermore. The birds of our country will bring you delicious berries; the dogs of our city will furnish you with innumerable bearskins, and your home will be made of beautiful cedar all inset with most lovely abalone shells. Come with us into our land of sunshine and be a great chief attended with numerous slaves. Come with us and the hairseal will provide you with salmon, halibut, and all kinds of shellfish. Come with us now," the spirits say, "for the tide is about to ebb and we must VOL. XXI. 
depart." At last the soul of the deceased man leaves his body to join the company of his former friends, and his body is buried with great pomp and splendour.

In regard to the wicked Indians, great clouds appear in which are the satellites of the cloud monarch who are ready to pounce upon their souls as soon as the body dies. They have no beautiful houses to dwell in, and no good food is supplied them. They are compelled to live with this dreaded chief twelve months, and after their bodies are buried, their souls are commanded to descend to the earth and bring their bodies to supply their chief with food. Should they refuse to accede to his request, he then begins to feast on their spirits, the consequence of which is, that their souls will immediately die. When the twelve months expire, he conveys their souls, if obedient, down through the sea, and the land beneath the sea, into the kingdom of Hetgwaulana.

The good land is heaven, and is called "shā tligê," the land above. The Good Chief is the reigning monarch in the land above, and the souls of the good Indians are taken there by his emissaries and presented with everything that could be wished for, after they have successfully passed through the domain of Chief Death. In heaven everybody is happy. There, in the land of the Great Chief, is perpetual light, with no clouds, no storms, and no fierce winds to mar the peace of his friends. There, they are clothed in beautiful garments made of cedar and spruce root and hunt and fish the livelong day. There, they dance their best dances and sing their favourite songs in the presence of their chief continually.

Hetgwauge is the name of the lower region over which Hetgwaulana is the chief. To this place Chief Cloud conducts the souls of the wicked Indians, and there they are prevented from hunting and fishing, and all enjoyment is at an end. It is a most dismal region to live in, as it is always dark, with terrible storms, and cold winds blowing continually. The storms prevent them from catching fish, and the snow prevents them from hunting, and thus they are in a state of perpetual misery and trouble.

The question naturally arises, what makes a good Indian, and what constitutes a bad one? The good Indians are those who worship the Great Chief through the minor deities; are punctual in offering sacrifices to the inferior gods; and are obedient to the commands of the great medicine man known as Saagga. They must also love their friends, and be kindly disposed towards the poor. They must never fight with their friends, but must always attend the great dance festivals and give liberally towards the feasts. They must only go to war against a foreign tribe at the command of the Saagga, who will then assure them of 
victory. If anyone be killed by an accident or in actual warfare the services of the Saagga will gain him an admittance into heaven. For which service the Saagga was accustomed to receive a bale of blankets valued ac $\$ 60$. Finally, all who are happy while on this earth will be admitted by the Great Chief into his eterual kingdom, where they will continue to be happy without end.

The wicked Indians are those who are always quarrelling and fighting. They have no desire to love their friends, and their only wish is to steal the property of the good Indians. The greatest sin a Haida can commit is to disregard the commands of the medicine man. All bad Indians hate the Saagga, despise his authority, and are consequently sent by him to the lower region. In general it is safe to say, that all who are unkind one to another, all who are quarrelsome, all who steal and commit murder, and all who disobey the medicine man, will be handed over by Chief Cloud to Chief Hetgwaulana after he has feasted on their bodies.

The Haidas believe that the soul leaves the body immediately after death, and is taken possession of either by Chief Cloud or Chief Death. The good soul is taken possession of by Chief Death, and during its sojourn in the Domain of Death it is taught many wonderful things, and becomes initiated into the mysteries of heaven. At last he becomes the essence of the purest light and is able to revisit his friends on earth. At the close of the twelve months' probation the time of his redemption from Death's kingdom arrives. As it is impossible that the pure essence of light, which is Shānungetlagidas, should come into contact with a depraved material body, the good Indian assumes only its appearance, and then the gates of cedar, beautifully carved and ornamented with shells, are thrown open, and his soul which by this time assumes the shape of his earthly body, but clothed in the light of the Kingdom of Light, is delivered to the Chief of Light by Chief Death in whose domains he has been taught the customs to be observed in heaven.

The bad Indian in the region of the clouds is tortured continually. In the first place his soul has to witness the chief of that region feasting on his dead body until it is entirely consumed. Secondly, he is so near to this world that he evinces a longing desire to return to his friends and gain their sympathy. Thirdly, he has the dread of being conducted to Hetgwaulana ever before his mind. No idea of atonement for his past wicked life is ever permitted, since his soul after death is incapable of reformation and consequently incapable of salvation. Sometimes permission is granted to souls in the clonds to revisit the earth. Then they can only be seen by the Saagga, who describes them as 
destitute of all clothing. They are looked upon as wicked and treacherous spirits, and the medicine man's duty is to prevent them entering any of the houses; and not only so, but as soon as the Saagga makes the announcement that a certain soul has descended from the clouds, no one will leave their homes, because the sight of a wicked soul would cause sickness and trouble, and his touch, death.

Now it sometimes happens that the souls in the Domain of Death are not made pure and holy within twelve months, and yet when their bodies died they were not wicked enough to be captured by Chief Cloud. Then it becomes necessary that the less sanctified souls return to earth and become regenerated. Every soul not worthy of entering heaven is sent back to his friends and reborn at the first opportunity. The Saagga enters the house to see the newly born baby, and his attendant spirits announce to him that in that child is the soul of one of their departed friends who died during the preceding year. Their new life has to be such as will subject them to retribution for the misdeeds of their past life, and thus the purgation of souls has to be carried on in successive migrations until they are suitable to enter the region of eternal light.

Likewise it sometimes happens that some souls are too depraved and wicked after twelve months' sojourn in the clouds to be conducted to Hetgwaulana, that they also are sent back to this earth, but are not allowed to re-enter mankind. They are allowed to enter the bodies of animals and fish, and compelled to undergo great torture. These evil souls are commanded to hurt all strangers, but have not to molest persons of their own tribes. The black bear is the most powerful creature that such a soul could inhabit, and the mouse is the smallest one. The animals and fish inhabited by evil spirits are also continually afraid of being killed, and it appears to me that this state of suspense is the means by which they could re-enter the clouds, and be finally conducted into the presence of Hetgwaulana. Thus it is that the ancient Haidas always used to wear an amulet of a bear's tooth around their necks to protect them from the wicked soul of the bear. Storms and bad weather, when they cause the people trouble and a scarcity of food, were attributed to an abundance of wicked souls in the vicinity.

Sometimes the soul enters into the body of a fin-back whale, and consequently fin-back whales are much honoured and at the same time feared. On no account could an Indian a few years ago be persuaded to shoot one. Sometimes a solitary whale enters the inlet and appears opposite to an Indian house. Then the inhabitants are in a great dread of capsizing at sea, and if 
such should be the case they will most assuredly be seized for Chief Cloud.

Take the mouse for another example of the strange and demoniacal notions that exist amongst the elder portion of the community even at the present time. This harmless little creature is magnified into such proportions at times that it can contain the wicked soul of an adult, and yet become so small that it can enter into the stomach of the living. The ancient Haidas firmly believed that in every one's stomach existed a number of mice, and each mouse represented the wicked and restless soul of a departed relative. Therefore a bad-tempered man was the possessor of a mouse that was possessed by a soul that was too ill-tempered to be introduced to Hetgwaulana. A man who was always quarrelling and fighting was supposed to have within him a soul who in his former life was addicted to such vices. The great question to consider is, how do the mice get into the stomach? Chief Edenshaw, the superior chief of the Haida nation, now 90 years of age, calmly and quietly told me that one bright summer's morning, having got up very early, he went for a stroll over Rose Spit and came upon some women who were sound asleep. To his horror and great astonishment he saw that their faces were covered with mice. He sat down quietly and watched them. Presently he saw one disappear down a woman's throat, then another, and quickly no less than seven vanished down her throat. Out of the seven that had disappeared only one returned as he had evidently gone down the throat of one of his tribe instead of the throat of an enemy. This left six woebegone souls inside of this most unfortunate woman. I did not ask him what became eventually of the woman herself, but doubtless, from the number of malevolent spirits located within her, she must have finally become a dainty dish for the Cloud Chief.

\section{Part II.-Creation of the Haidas.}

Now the question arises, how were the Haidas created, and by whom? Thousands of years after Hetgwaulana was cast forth from the region of the clouds he commanded one of his followers to assume the shape of a bird and make an attempt to discover what the gods in the Kingdom of Light were occupied with, and also obtain information if possible how they in the region of darkness could again ohtain admission into their long lost country.

This god assumed the form of a Raven, and after his first attempt to obtain information about Shānungetlagidas had been frustrated he determined never to return again to the dismal 
abode of his associates but remain an inhabitant of the air and be at liberty to do what he pleased. Thus in the earliest ages the Raven was supposed to live in the grey clouds which overshadow the mighty deep, and had no place of refuge and no place on which he could rest. At this period there was no dry land and the face of the earth was covered with water. At last the Raven grew very angry, being very weary, and beat the water with his wings until it flew up in great clouds on each side of him, and in its fall became transformed into tiny rocks, and so at last he found a resting place.

These rocks grew larger and larger and extended themselves on every side until at last they reached from North Island to Cape Saint James. Some years afterwards the rocks underwent another change and became transformed into sand, upon which a few trees eventually grew, and this became Queen Charlotte Islands and the country of the Haidas.

The Raven then wished some one to assist him in cultivating his newly-made world. He therefore collected together two large mounds of clam-shells on the beach near Sisk and made them human, and afterwards compelled those now made to become his slaves. At last the two slaves became dissatisfied with their condition and told the Raven that they were not properly made. In anger the Raven listened to their piteous story, and then concluded to make them male and female. He threw limpets at one which eventually became the man, and the other remained as she was before, a woman. Thus were created the first parents of the Haida nation. Some time ago a little Haida boy was asked who had made him. Without stopping to consider, he promptly answered Yettlth the Raven. This goes to prove that until quite recently the Haidas fully believed the Raven to be their creator.

The creator lived at the north-eastern point of Graham Island at a place called Rose Spit. This place is twenty-six miles distant from Massett. He presently grew weary with his lonely life and at last commanded the female slave to be his wife. They lived peaceably and happily together for a number of years, but at last he became angry with her, and sent her and the man slave away to a place now called Skidegate, because she bore him no children.

Being left quite alone, he came to the determination to again gain admittance into the Kingdom of Light, not to please, however, the Chief of Darkness, but to gain his own ends and secure a beautiful wife from among the daughters of the heavenly chiefs. One bright summer morning he started off on his long and weary journey. He soared upwards and onward over the lonely sea, until the land he had created appeared to 
him to be a small mosquito. Upwards he soared into the clear blue sky until at last he came to the walls of heaven. He concealed himself until the evening, and then assumed the form of a bear. He then scratched a hole through the wall and entered his former abode.

The place had greatly changed since the time he was an inhabitant there, and consequently he took time to consider everything that he saw so as to form a similar kingdom on his return to earth. There he found that everyone was considered a god or a chief, and all were submissive to the Chief of Light, who still held supreme power as in olden times. He also found that the Great Chief had divided his kingdom into towns and cities, into lands and seas, and had created the moon and the stars, and made a great luminary to rule over all, which was called Juie, the sun. At last he was caught by the hunters of the king and brought into his presence. As the Raven appeared to be a beautiful and tame bear, he was kept as a playmate for the king's youngest son. He then spent three years in intimate connection with the royal family, and had sufficient time to make careful and necessary observations prior to his descent to the lower world. He determined to found a dynasty as powerful as the one over which Shānungetlagidas held control, and that his peopie also should be as numerous as the inhabitants of heaven.

It was customary for the children in the Land of Light to disguise and transform themselves into bears, seals, and birds. Now it so happened that the Raven who had become a bear was strolling on the beach one evening, looking for his supper of clams, when he espied three other bears approaching him. He knew at once that they were children of a great chief, and instantly he transformed himself into a large eagle, stole the sun, which happened to be setting at the time, also the fire stick that was used to kindle the heavenly fires, and flew over the walls of heaven with one under each wing, together with the child of a great chief in his beak.

As soon as the people found that the sun had been stolen, they reported the matter-at once to the king. He then ordered his kingdom to be searched, and if the culprit were found he was condemned to be thrown down to the kingdom of Hetgwaulana. Whilst they were busy searching for the thief, a messenger arrived, who stated that he had seen a large eagle flying over the walls of their city with the sun under his wing. At once, all the heavenly citizens gave chase, and the Raven was pursued. In his flight for safety, he dropped the child and it fell down through the clouds, and down into the sea close to the Raven's kingdom. The Raven also descended, bearing 
with him the sun and the fire stick in safety to the earth. When the child fell into the sea, he cried aloud for assistance, and immediately the little fishes came in great shoals to his aid and carried him on their backs safely to the shore. This fish is very numerous around Rose Spit at the present day, and their forms have remained dinted in the blue clay of that district from the day when they bore the heaven-born child ashore until now. The Great Chief was a lover of peace, and consequently did not allow his followers to pursue the Raven down to the earth, as Chief Hetgwaulana might then be tempted to regain heaven and give them perpetual trouble. So the Raven was unmolested, and another sun was created in heaven by the Great Ruler who loved light and hated darkness.

Now the Raven thought that he had secured a chief's daughter, but it turned out to be a great chief's son. The Raven loved him exceedingly, and built a house at Rose Spit especially for the accommodation of the child and the sun. The child grew to be very powerful and had command over all animals, fish, and birds. Whenever he called to the fish they would at once appear and bear him out to sea. Whenever he wished to fly through the air he would call to the birds. They would at once come and bear him wherever he wished to go on their wings. The bears and other animals attended to his daily wants and supplied him with salmon and berries. The animals, birds, and fish were created by the Raven for the sole benefit of this heaven-born child. The Raven also kept the sun and the fire stick in a very strong and secure room, as he was afraid that his two former slaves would return and steal them.

Presently the slave wife of the Raven returned and begged to be readmitted into the Raven's society. The request was granted, and she became once more the mistress of the Raven's household. She took a great interest in the child and attended to his every wish. By this time the child had grown to be a handsome young man and began to love this woman. She reciprocated his love and at last resolved to become his wife. The Raven soon found that they were acting as man and wife, and he became very angry. He threatened to kill the woman. This threat caused the lovers to escape from the house and hide themselves in the bush. When they escaped from the Raven's house, they carried with them a large cedar box, in which the sun and the fire stick were placed. Day after day, and month after month, they wandered southward without proper nourishment and in great fear of the Raven. They also carried with them the box containing the sun and the fire stick.

One evening, faint and weary, they sat down near a little 
creek, and the woman, being very hungry, wept bitterly. Her husband walked a little distance up the stream, and at last found a dead land otter, but could not eat it as they had no fire to cook it. Next morning, they remembered that they had the fire stick in the box that they were carrying. They determined to try it. The young man got it and instantly made fire, and the two cooked the body of the otter, ate it, and proceeded on their journey. When they reached Cape Ball, they were hungry again, but the young man began to sing some of the songs taught him in heaven, and the sea receded four miles from the shore and left one great whale stranded on the beach. The young man got rocks and stones, and carried them on his back to where the whale was, and barred it in, and thus described a circle around it that can be seen at the present day.

The young man and his wife lived on whale flesh until they reached the channel that divides Graham and Moresby Islands, and there they built a house, which afterwards became the nucleus of the Skidegate village. There they lived for several years in peace and prosperity, and a daughter was born which made them exceedingly happy. In time their daughter grew to be a beautiful woman and most lovely to behold, but the great drawback to her peace of mind was that no husband could be found for her.

Year after year passed by, and when her parents had given up the idea of providing her with a husband, there came from North Island, around the west coast, the Raven's male slave that he had made on the beach at Sisk, and this forlorn specimen of early man desired the hand of this lovely damsel in marriage. Her father refused to give his consent, and was very angry at the impudence of a clam-shell-made man in daring even to think of becoming united to the daughter of a heavenborn chief. The slave was not so easily to be got rid of, so he lived in the woods near the house, and whenever the husband was away from home would come and talk with his wife, who was the same woman that was made by the Raven at the time of his creation. This woman treated him as her brother, and told him all her secrets, and even went so far as to reveal to him the place where her husband kept the chest containing the sun that he had stolen from the Raven's house at Rose Spit.

This treasure was safely stored in a strongly built house in the woods where the heaven-born man would frequently go to pray to the gods in the Kingdom of Light. It was bad policy for the woman to divulge the whereabouts of her husband's great treasure, for the heaven-born chief, on the slave appealing for the last time for his daughter's hand, kicked him most 
unceremoniously from the house. In revenge, the chief having retired for the night, the slave went to the house in the woods, descended through the smoke hole, and found the box, which contained the sun. He seized a large club that was on the floor and destroyed the box, taking great care of the sun which he had first abstracted. He then sat down and pondered over his lonely lot in life, and became at last so mad that in anger he kicked the sun until it was broken into fragments, and each viece flew up through the smoke hole into the sky. The largest piece became the sun, a smaller one the moon, and all the chips lecame stars scattered upon the face of the heavens. Thus were created the sun, moon, and stars of the Haida country.

It is curious to note that the heaven-born chief was allowed to marry an earth-born slave, but the earth-born slave was not allowed to have the daughter of the heaven-born chief for his wife. This is adhered to at the present day. A chief is allowed to marry a female slave, whilst the male slave is not allowed to marry a free-born woman, thus following the supposed laws of their creator-the Raven.

The slave at once realised the terrible position in which he was situated; for, had the chief found him he would most undoubtedly have been killed. So before the dawn of the following morning he was well on his way on the west coast to his former abode at the North Island. He travelled by night and slept in the woods during the day, thus avoiding the keen eye of the Raven and the meeting of the Chief. At last he reached home and sat brooding over his misfortunes, until the happy thought entered his mind of doing what the Raven had done, and to seek his wife from amongst the daughters of heaven.

At this period of the world's civilization they possessed bows and arrows made after the manner of those seen by the Raven when in the Kingdom of Light. They also had the sun to give them heat during the day, and the moon and stars to give light by night. So on one bright moonlight night he shot an arrow into the moon so that it remained there. A second arrow he shot into the notch of the first, a third into the notch of the second, and continued to do so until the arrows reached from the moon to the earth. He was very energetic in his work, for he shot no less than three hundred and sixty-five arrows, which took him three hundred and sixty-five nights to accomplish, and which ultimately got transformed into so many days and nights that finally they became the days of the Haida year.

Up this ladder of arrows he climbed and passed through the moon into heaven. Early in the morning of the first day that he arrived there he saw a beautiful woman swimming in a lake of 
crystal. He stealthily went round to the side on which she was likely to step ashore, and awaited her arrival. She soon came: but no sooner did she set her foot on the beach than she was seized by the slave with whom he dropped into the sea not far from North Island.

The Raven happened to be flying near North Island during the descent of the slave, and noticing something extraordinary in the atmosphere he watched, and at last discovered what he thought to be two large eagles were the slave and the beautiful woman. No sooner did the slave lead her into his house than the Raven appeared. The Raven demanded that the slave should give him this beautiful woman, but he refused to do so. Whereupon the Raven became very angry, took possession of the woman as his wife, and most unceremoniously changed the slave into a spirit, and drove him away from him for ever. $\mathrm{He}$ cursed the slave most bitterly and commanded that he should always be a wandering spirit to look after the growth of every living thing.

Thus the wanderer, as the slave is now termed, is always busily engaged causing the berries and roots to grow for the support of the Haidas. Every plant, every flower, and every tree are under his control; and he it is that provides fine cedar trees on the islands, out of which the natives dig their canoes. The beasts of the forest, the fish in the sea, and the birds of the air are under his supreme control. At the present time he is fulfilling his destiny, and at times the Haidas think with gratitude of his goodwill toward them, and offer him sacrifices of berries, roots, salmon and bear-grease. These they put into hollow trees to provide a meal for their most unfortunate ancestor, should he require anything to eat. Thus he wanders upon the face of the earth both night and day, and must continue to roam apart from his descendants, until the end of all things. At the end of time, when the Raven shall become dissatisfied with the existing state of affairs he will recall him, and woe to the Haidas when he is recalled! for the trees and plants, the fish and animals, the fowls of the air, and even their country will most undoubtedly cease to be, and then shall the end of the Haidas come.

Mr. HaRRISON has since contributed the following notes in reply to various questions raised during the discussion :-

Firstly. Many of the visitors to Queen Charlotte Islands are of the opinion that the ancestors of the Haida nation were blown out to sea from some of the harbours of Japan, and having lost all bearings were eventually driven across to the islands. 
Quite recently Japanese junks have been found on the west coast dashed to pieces against the rocks. If their junks have been washed across to our shores there is no reason why junks manned by Japanese may not at an earlier date than the white man's knowledge of the Haidas have been successfully sailed or blown across by stormy winds. This has a tendency to confirm the opinion of those who believe that the Haidas originally came from Japan. At any rate they are a distinct race of people. Their language, also, is quite distinct, and has no resemblance whatever to the languages spoken by the neighbouring tribes on the mainland.

Secondly. Juan Perez was the first white man to discover the islands in 1774, and they were named by him Cabo de Saint Margarita. It is now one hundred and sixteen years since the Haidas first came into contact with our race. And for the greater part of this time they have been associated, not with the good, but with the evil.

Thirdly. The Haida months are :-

Kêtas: September.-This month they get the cedar bark.

Kalk Kungas: October.-Ice moon.

Cha Kungas: November.-The bears paw the ground for roots.

Gwoug̃iangas: December.-Too cold to sit on the beach this month.

Lthkittūn Kungas: January.-Goose moon.

Tān Kungas: February.-The bears begin to come out of their holes.

Yhìtgaas: March.-Laughing goose moon.

Whittgaas: April.-Foreign goose moon.

Tāhellè Kungas : May.-The month of flowers.

Hānskile Kungas: June.-The berries begin to ripen this montb.

Hānalung Kungas: July.-Moon in which the berries are ripe.

Chīn Kungas: August.-Salmon moon.

Kishalsh Kungas.-Moon in which they smoke their salmon.

They always smoke their salmon between July and October.

There are twenty-eight days in each Haida month, and thirteen times twenty-eight make three hundred and sixty-four. The difference of one day between the Haida year and ours they 
explain by saying that one day was spent by the Raven's slave in climbing the ladder of arrows to secure a heaven-born woman for his wife. This day must be reckoned at the end of the thirteenth month, and will then make their year to correspond with ours.

Fourthly. The medicine men were supposed to be in communication with Chief Cloud, and they alone were able to commune at any moment with the spirits of the departed, during their year's residence in the clouds, or in the domain of Chief Death. All wicked Indians were those who refused to obey their commands, and their spirits were taken possession of by Chief Cloud. The Haidas formerly placed the dead bodies on the highest branches of the spruce trees. If the medicine men were not well paid by the deceased man's relations they would go by night, take down his body from the tree, bury it in the ground, and then declare that Chief Cloud had sent the man's spirit to bring his body into the clouds to furnish him, i.e., the Chief, with a meal.

Fifthly, The medicine man is the supposed possessor of all knowledge, not of the present world alone, but also of the world to come. He is able to turn himself into any animal at any time, and all diseases are subject to his incantations. At any moment he can commune with the spirits of the departed, and to him the enemies of the tribe must yield. Thus from the cradle to the grave the destinies of the tribe are subject to his whim, and consequently he ranks as a very great chief.

\section{Discussion.}

Mr. Bouverie-Pusey asked whether, according to the myths of the Haidas, any children were born to the women of heavenly origin spoken of in the paper, and whether any of their blood was supposed to remain in the existing human race.

Dr. Tylor, Mr. Galton, and Mr. Lewis joined in the discussion, and the Author replied.

Miss BuckLand also contributed a Note on the subject of the Paper, which was read by the President.

\section{Note by Miss A. W. Buckland.}

In my paper on "Traces of Pre-Historic Intercourse between East and West," published in the "Journal " for February, 1885, I called especial attention to some remarks by $\mathrm{Mr}$. Wm. Wall in his extremely interesting and instructive article upon "Masks, Labrets, and certain Aboriginal Customs," published in the Third Annual Report of the Bureau of Ethnology, Smithsonian Institution. The point to which I particularly referred was the existence, as pointed 